wise foreign to deposits of marine origin; and all those which we know, have been found buried in lacustrine formations, at whaterer epoch of the Tertiary period they may have lived. It is under these conditions that we meet with them at Aix in Provence, at the Puy en Velay, in the Limagne d'Aurergne, and in the gypseous deposits of the neighbourhood of Paris.--Comptes Rendus, August 31, 1874, tome lxxix. p. 557.

On Fossil Evidences of a Sirenian Mammal (Eotherium ægyptiacum, Ow.) from the Nummulitic Eocene of the Mokattam Cliffs, near Cairo. By Prof. Owen, F.R.S., F.G.S., \&c.

The specimens described in this paper were obtained by Dr. Grant, of Cairo, in a block of the white limestone of the Cerithian Nummulitic zone, quarried extensively for building-purposes in the Mokattam Cliffs. They consisted of a few fragments of the base of the cranium and a cast of the entire brain with the commencement of the myelon. The author discussed the characters presented by these remains, which he regarded as having belonged to an extinct sirenian, probably allied to Halitherium, which he proposed to name Eotherium agyptiacum. The characters of the brain, as deducible from the cast, were detailed, and shown to be sirenian. By comparison with the brains of other Sirenia, the author was led to trace a progress in the cerebral characters of the animals of this type, from its first known appearance in the Nummulitic formation of Egypt to the present day. He also inferred, from its presence in the Nummulitic limestone, that this rock had been deposited not far from a shore.Proc. Geol. Soc. Nov. 18, 1874.

\title{
Coal of the Carboniferous Era not made of Bark.
}

The suggestion has been made, in view of the many Sigillariastumps hollowed out by decay, and flattened stems of other trees, found in the coal-measures, filled with shale or sandstone, that the vegetable débris from which the coal has proceeded was largely bark, or material of that general nature. But the occurrence of such stumps and stems outside of the coal-beds, while proof that the interior wood of the plants was loose in texture and very easily decayed, is no evidence that these trees contributed only cortical portions to the beds of vegetable débris. Moreover the cortical part of Lepidodendrids (under which group the Sigillarids are included by the best authorities), and of Ferns also, is made of the bases of the fallen leaves, and is not like ordinary bark in constitution; and Equiseta have nothing that even looks like bark. This cortical part was the firmest part of the wood; and for this reason it could continue to stand, after the interior had decayed away, - an event hardly possible in the case of a bark-covered Conifer, however decomposable the wood might be. Further, trunks of Conifers are often found in the later geological formations, changed, throughout the interior, completely to brown coal or lignite.-Dana's Manual of Geology, New Edition, p. 362. 


\section{$2 \mathrm{BHL}$ Biodiversity Heritage Library}

1874. "Coal of the carboniferous era not made of bark." The Annals and magazine of natural history; zoology, botany, and geology 14, 463-463. https://doi.org/10.1080/00222937408681015.

View This Item Online: https://www.biodiversitylibrary.org/item/63340

DOI: https://doi.org/10.1080/00222937408681015

Permalink: https://www.biodiversitylibrary.org/partpdf/58784

\section{Holding Institution}

University of Toronto - Gerstein Science Information Centre

\section{Sponsored by}

University of Toronto

\section{Copyright \& Reuse}

Copyright Status: NOT_IN_COPYRIGHT

This document was created from content at the Biodiversity Heritage Library, the world's largest open access digital library for biodiversity literature and archives. Visit BHL at https://www.biodiversitylibrary.org. 